\title{
Laudatio for Professor Sergio Giovannetti
}

It is for me both an honor and a privilege to write this introduction to the Laudatio in honor of my co-editor Professor Sergio Giovannetti, mixed with sadness at his departure from Nephron over so many fruitful years where I have benefited from his wise counsel and guidance and during which period we have never had a disagreement about any paper presented to us during this time. First let us look at the standard biographical facts which do little to illuminate this extraordinary man and his major contribution to nephrology.

Sergio Giovannetti qualified MD at the University of Pisa in 1949. He became professor of medicine in 1964.

In his alma mater and since 1974 he was Chairman of the Postgraduate School of Nephrology in the University of Pisa. He was chairman of internal medicine 19781994, and since 1994 has held the Chair of Nephrology in the same university. He has published more than 200 scientific original articles and two well-known and highly praised books. His interest in dietary therapy did not keep him from having a great interest, as his papers show, in dialysis and in transplantation, and he has raised many first-class nephrologists who continue to work with him and after he has retired his legacy will live in their excellent original and important renal research.

Sergio Giovannetti is a great man, a leading clinical nephrologist and a precise physiologist whose accomplishments span many years and always remain at the cutting edge of knowledge. His work has always been closely linked with the disease process, and how it can be ameliorated. As a result of his work past and present, many patients have benefited directly; their length of life increased, and their life quality improved, often beyond all recognition. Few nephrologists can claim this happy in-

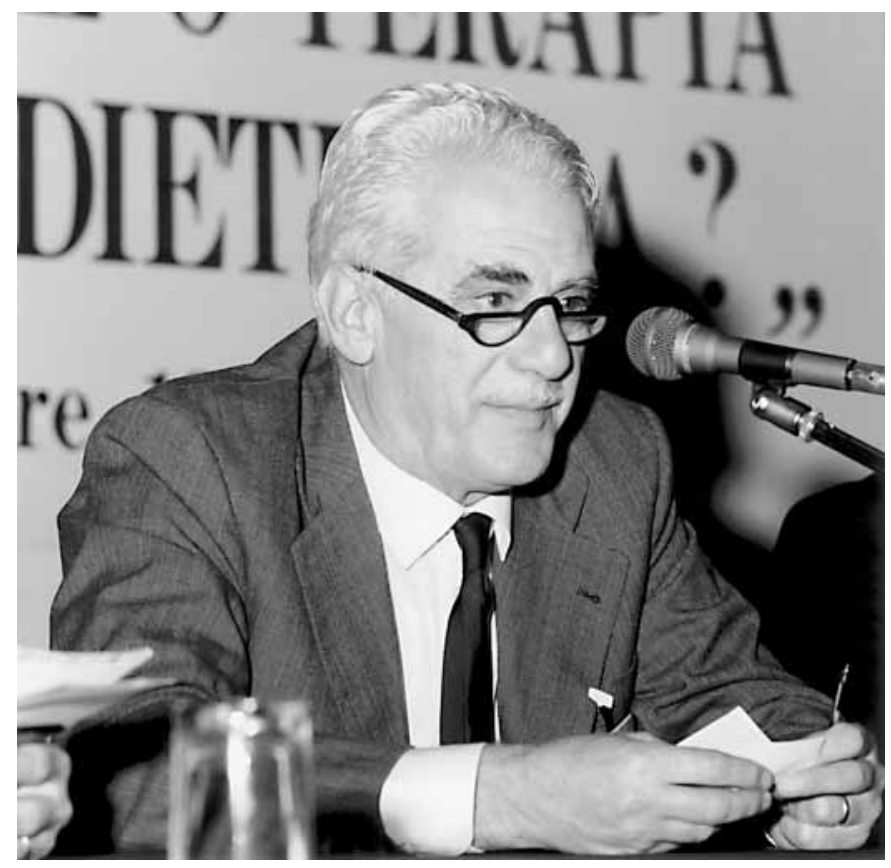

fluence on clinical disease progress, other than Belding Scribner who introduced regular hemodialysis. The rest of the nephrological community engaged in research is often content to unearth a few facts which contribute in the long term to our understanding the origins of disease and suggest possible lines of treatment. Few of us are Giovannettis.

In the early 1960s I remember reading his classic paper on the effect of a low-protein spaghetti diet in ameliorating uremia and its symptoms. In those days dialysis was just starting, and regular dialysis was just being devel-

\section{KARGER}

Fax +41613061234

E-Mail karger@karger.ch www. karger.com

(c) 1999 S. Karger AG, Basel

0028-2766/99/0814-0373\$17.50/0

Accessible online at:

http://BioMedNet.com/karger
} 
oped, so there was little chance for most patients in endstage renal disease to get dialyzed, and Giovannetti's work gave several months of extra life to this group. My group working in Manchester adopted his diet for Western European tastes, and its success was remarkable. His basic work on the importance of methylguanidine in the pathogenesis of the uremic syndrome is outstanding and is the best explanation of the cause of uremic pericarditis to this date. It also gave further stimulus to multiple studies by others to find the identity of uremic toxins, and this has proved to be a rich field of research. Giovannetti's work on the guanidines can be said to have been responsible then for a major advance in our knowledge of the entire subject of uremic toxins.

His work on diet has been continuous, demonstrating the increase in survival in patients with advanced renal disease, and the slowing of deterioration in renal function as a result of very low protein diet, and of particular importance are his results in the very low protein vegetarian diet which he introduced and which is capable of halting deterioration of renal function totally and over a period of years. In addition, his research on hormonal and metabolic effects of various low-protein diets in patients with chronic renal failure has been striking and improved our understanding of the various factors contributing to the uremic state.

In his retirement from Nephron I am sure he will find a positive aspect - a little more time to organize further international trials and to continue in the singularly fruitful path which this remarkable man has been following since his graduation in 1949. We wish him health and happiness to continue to stimulate us intellectually and to continue to benefit mankind with his research.

G.M. Berlyne 